\title{
HAMBATAN GURU MATEMATIKA SEKOLAH MENENGAH PERTAMA DALAM MENERAPKAN KURIKULUM BARU
}

\author{
Heri Retnawati \\ Fakultas Matematika dan Ilmu Pengetahuan Alam Universitas Negeri Yogyakarta \\ email: heri_retnawati@uny.ac.id
}

\begin{abstract}
Abstrak: Penelitian ini bertujuan mendeskripsikan hambatan guru matematika SMP dalam mengimplementasikan Kurikulum 2013. Penelitian ini merupakan penelitian deskriptif eksploratif dengan pendekatan kualitatif. Data dikumpulkan dengan teknik wawancara dan focus group discussion. Sumber data adalah 10 guru mata pelajaran matematika SMP di Provinsi Daerah Istimewa Yogyakarta. Analisis data dilakukan dengan mencari tema, kemudian menentukan hubungan antartema untuk memeroleh pemahaman. Hasil penelitian sebagai berikut. Pertama, pelatihan dan sosialisasi belum dapat memberikan pemahaman yang baik dan menyeluruh mengenai Kurikulum 2013. Kedua, guru kesulitan mengatur waktu pada perencanaan pembelajaran, merencanakan pembelajaran, merencanakan penilaian sikap, dan memilah pengetahuan dan keterampilan pada penyusunan instrumen penilaian. Ketiga, keterbatasan waktu dalam pelaksanaan pembelajaran, kesulitan berkaitan dengan perangkat pembelajaran, dan kesulitan mengaktifkan siswa. Keempat, sistem penilaian yang rumit dan perlu waktu yang lama untuk menyusun laporan.
\end{abstract}

\section{Kata Kunci: hambatan guru matematika SMP, implementasi kurikulum baru}

\section{THE OBSTACLES OF JUNIOR HIGH SCHOOL MATHEMATICS TEACHERS IN IMPLEMENTING THE NEW CURRICULUM}

\begin{abstract}
The study was to describe the obstacles of junior high school mathematics teachers in implementing the new curriculum, namely Curriculum 2013, in most of junior high schools in Indonesia. The study was a descriptive explorative research by means of qualitative approach. The data were gathered by means of interviews and focus group discussions. The data source was 10 junior high school mathematics teachers in the Province of Yogyakarta Special Region, Indonesia. The data were analyzed by looking for the themes and finding the relationship among the themes in order to gain the proper understanding. The results of the study showed that the obstacles that the teachers were as follows. First, the socialization and training programs had not been able to provide good and through understanding of the new curriculum. Second, the teachers had difficulties in arranging the time for the lesson plan, the teaching plan, the attitude assessment plan and the categorization between the knowledge and the skills in the composition of assessment instrument. Third, the implementation of the lesson plan had limited time in addition to the difficulties in designing the teaching kits and in activating the students. Forth, the assessment system was intricated and time consuming especially in the reporting process.
\end{abstract}

Keywords: obstacles of junior high school mathematics teachers, implementing new curriculum

\section{PEDAHULUAN}

Meningkatkan sumberdaya manusia merupakan tujuan setiap bangsa. Tujuan tersebut dapat dicapai di antaranya melalui pendidikan. Pendidikan dikembangkan terus-menerus se- iring dengan dengan perkembangan peradaban, ilmu pengetahuan, teknologi, dan seni. Upaya perbaikan kualitas pendidikan yang terus-menerus ini diwujudkan dalam bentuk perubahan kurikulum. Perubahan kurikulum meliputi muatan 
pendidikan, proses pembelajaran, maupun penilaian. Perubahan kurikulum ini telah dilaksanakan oleh berbagai negara. Negara-negara yang melakukan perbaikan kurikulum di antaranya adalah Korea (So \& Kang, 2014), Eropa (European Centre for the Development of Vocational Training, 2012), Hongkong (Cheung\& Wong, 2012), China (Tanja, 2011), negara-negara di Asia dan sekitarnya (Unesco, 2014), Turki (Osturk, 2011), Pakistan (Hussain, Adeeb, Aslam, 2011) dan juga negara-negara lain. Demikian pula halnya dengan perbaikan kurikulum di Indonesia.

Pada tahun 2013, pemerintah Indonesia memberlakukan kurikulum baru untuk pendidikan di sekolah dasar dan menengah di Indonesia, yaitu Kurikulum 2013. Kurikulumini bertujuan untuk meningkatkan kualitas sumberdaya manusia dan meningkatkan daya saing bangsa, dan seiring dengan perkembangan ilmu pengetahuan, teknologi, dan seni. Kurikulum ini diharapkan menghasilkan sumber daya manusia yang produktif, kreatif inovatif dan afektif, melalui penguatan kompetensi sikap, pengetahuan, dan keterampilan (Puskurbuk, 2012). Tujuan ini dilakukan melalui pelaksanaan pendidikan dengan memperbaiki muatan pendidikan, melakukan pergeseran paradigm belajar ke konstruktivisme, dari siswa menerima materi menjadi siswa membentuk pemahaman konsep dalam mata pelajaran sendiri, menggunakan penilaian berbasis kompetensi, dan penilaian kelas secara otentik.

Muatan tiap mata pelajaran yang dipelajari siswa meliputi 4 kompetensi inti, yaitu kompetensi sikap sosial, sikap spiritual, pengetahuan, dan keterampilan (Menteri Pendidikan dan Kebudayaan, 2013). Masing-masing kompetensi kemudian dijabarkan menjadi beberapa kompetensi dasar. Keempat kompetensi inti masing-masing diberi penelakanan yang sama. Hal ini yang membedakan Kurikulum 2013 dengan kurikulum yang berlaku sebelumnya. Penekanan bukan hanya pada kompetensi kognitif saja, namun juga pada kompetensi sikap dan keterampilan juga menjadi hal penting untuk dipelajari dan dilatihkan kepada siswa.
Pada proses pembelajaran, digunakan paradigma konstruktivisme. Dengan kurikulum ini, direkomendasikan pembelajaran dengan pendekatan saintifik, pembelajaran berbasis masalah, atau pembelajaran berbasis projek (Menteri Pendidikan dan Kebudayaan, 2013). Sintakssintaks pembelajaran juga telah ditetapkan, yang diharapkan dapat mempermudah guru dalam melaksanakan pembelajaran. Dengan pembelajaran ini, siswa menjadi lebih aktif dan mengkonstruk pemahaman sendiri untuk menguasai kompetensi sikap spiritual, sikap sosial, pengetahuan, dan keterampilan.

Sistem penilaian yang dilaksanakan guru di kelas juga sangat berbeda dengan kurikulum sebelumnya, yaitu dengan menerapkan asesmen otentik. Penilaian dalam Kurikulum 2013 diatur dengan Peraturan Menteri Pendidikan dan Kebudayaan Republik Indonesia Nomor 81 Tahun 2013 (Menteri Pendidikan dan Kebudayaan, 2013) yang kemudian diperbaiki menjadi Peraturan Menteri Pendidikan Nomor 104 Tahun 2014 (Menteri Pendidikan dan Kebudayaan, 2014). Terdapat 4 kompetensi yang diukur pada penilaian ini, yaitu: kompetensi sikap spiritual, sikap sosial, pengetahuan, dan keterampilan. Untuk mengukur sikap spiritual dan sikap sosial, ada 4 teknik yang dapat digunakan, yaitu observasi, penilaian diri, penilaian antarpeserta didik, dan jurnal. Untuk mengukur pengetahuan, ada 3 teknik yang dapat digunakan, yaitu teknik tes, observasi, dan penugasan. Adapaun untuk penilaian keterampilan, ada 4 teknik yang digunakan, yaitu penilaian unjuk kerja, projek, produk, dan portofolio. Penilaian ini dilakukan pada setiap kompetensi dasar, pada tiap kompetensi dengan menyatukan hasil dari penilaian beberapa kopetensi dasar yang dipelajari, dan pada seluruh mata pelajaran di sekolah. Setelah itu, hasil penilaian dideskripsikan secara kualitatif pada tiap siswa untuk keempat kompetensi pada seluruh mata pelajaran.

Secara teoretis, pembelajaran pada Kurikulum 2013, khususnya dalam pelajaran matematika sejalan dengan pembelajaran matematika yang ditetapkan NCTM. Pembelajaran matematika yang dirumuskan oleh National Council of Teachers of Matematics (NCTM, 2000) 
menetapkan bahwa siswa harus mempelajari matematika melalui pemahaman dan aktif membangun pengetahuan baru dari pengalaman dan pengetahuan yang telah dimiliki sebelumnya. Ada lima standar proses dalam pembelajaran matematika, yaitu: (1) belajar untuk memecahkan masalah; (2) belajar untuk bernalar dan bukti; (3) belajar untuk berkomunikasi; (4) belajar untuk mengaitkan ide; dan (5) belajar untuk mempresentasikan (NCTM, 2000). Pada pembelajaran ini, aspek yang dikembangkan dalam pendidikan meliputi aspek sikap, pengetahuan, dan keterampilan. Pendidikan tidak hanya melatihkan pengetahuan dan keterampilam saja, namun juga aspek sikap. Keterampilan dalam matematika yang dimaksudkan adalah keterampilan berfikir tingkat tinggi (HOTS) yang mempengaruhi kemampuan siswa dalam berfikir kritis (Udi \& Cheng, 2015).

Pembelajaran saintifik merupakan pembelajaran yang mengadopsi langkah-langkah ilmuwan dalam membangun pengetahuan melalui metode ilmiah. Model pembelajaran yang diperlukan adalah yang memungkinkan terbu-dayakannya kecakapan berpikir sains, terkembangkannya "sense of inquiry" dan kemampuan berpikir kreatif siswa (De Vito, 1989). Pembelajaran saintifik dilakukan dengan tahap mengamati, menanya, mencoba, mengasosiasikan, dan mengomunikasikan. Pembelajaran ini dapat meningkatkan pemahaman siswa dari segi isi maupun pengalaman (Edelson, Gordin \& Pea, 1999). Selain pembelajaran saintifik, kurikulum merekomendasikan pula penggunaan pembelajaran berbasis masalah (problem based learning, PBL) dan pembelajaran berbasis projek (project based learning, PjBL). PBL dapat bermanfaat untuk meningkatkan keterampilan berfikir tingkat tinggi (Weissinger, 2004; Arends, 2012). Pembelajaran berbasis masalah merupakan pendekatan pembelajaran yang berpusat pada siswa yang mengorganisasikan kurikulum dan pembelajaran dalam situasi yang tidak terstruktur dan memberikan masalah dunia nyata (Mergendoller, Maxwell \& Belissimo, 2006; Massa, 2008; Arends \& Kilcher, 2010). Masalah dalam PBL berupa masalah autentik untuk dijadikan tonggak untuk melakukan investigasi dan penemuan (Arends, 2012), berkolaborasi dan mengatur pembagian tugas antarsiswa (Arends \& Kilcher, 2010). Demikian pula halnya dengan PjBL yang merupakan metode yang mendukung, memfasilitasi, dan meningkatkan kualitas pembelajaran (Tamin \& Grant, 2013).

Asesmen pada Kurikulum 2013 yang diterapkan adalah penilaian autentik. Penilaian otentik merupakan proses penilaian secara global untuk menilai secara mendalam pemikiran, motivasi, atau tindakan. Dalam penilaian ini, siswa diharapkan berfikir kritis, menganalisis informasi, memeroleh ide yang baru, mengomunikasikan, kerjasama, memecahkan masalah, dan menyimpulkan (DiMartino, Castameda, \& Miles, 2007). Pada asesmen otentik ini, kompetensi siswa dinilai, baik pengetahuan, keterampilan, atau sikap, atau kombinasi dari ketiganya (Gulikers, Bastiaens, Kirschner, 2004; Ariev, 2005; Lombardi, 2008).

Sebelum kurikulum dilaksanakan, hal yang penting untuk dilakukan pemerintah adalah melakukan manajemen yang baik. Manajemen yang baik ini menentukan keberhasilan pelaksanaan Kurikulum 2013 (Katuuk, 2014). Salah satu bagian yang perlu menjadi fokus perhatian dalam manajemen ini adalah sosialisasi dan diseminasi. Kegiatan ini dimaksudkan agar pelaksana kurikulum memahami sepenuhnya kurikulum sehingga dapat melaksanakannya dengan baik. Untuk kegiatan ini, banyak hal yang dapat dilakukan. Mayer \& Fortner (1987) menyatakan bahwa workshop yang intensif merupakan cara yang efektif untuk meyakinkan pemanfaatan materi kurikulum yang didesiminasikan. Cara lain yang dapat digunakan adalah pengembangan keprofesionalan guru terkait kurikulum (Ryder, Banner, \& Homer, 2014).

Ketika kurikulum baru diberlakukan, tentu ada hambatan untuk mengimplementasikannya. Hambatan dan tantangan yang biasa dialami dan dihadapi banyak negara yakni tahap implementasi, misalya tambahan tugas guru yang berat dan perbedaan-perbedaan dalam kelas yang dialami selama pembelajaran (Cheung \& Wong, 2012), kekurangcukupan pemahaman guru mengenai kurikulum (Park, 2008, Cheung \& Wong, 2012), dan kurangnya fasilitas 
(Syomwene, 2013). Selain itu, juga terdapat hambatan dalam pelaksanaan pembelajaran dan asesmen.

Pembelajaran dengan pendekatan konstruktivisme tidak langsung berjalan lancar seperti yang diharapkan. Pada pelaksanaan pembelajaran yang melibatkan kehidupan nyata, lingkungan belajar tidak berorientasi pada kehidupan nyata, lingkungan belajar tidak terkait dengan pengalaman belajar siswa, yang menyebabkan pendekatan kontruktivisme kurang efisien dan siswa kurang memeroleh otonomi belajar secara layak (Acat, Anilan, \& Anagun, 2010). Hambatan lain adalah guru-guru kesulitan untuk melaksanakan aktivias dalam kelas (Eraslan, 2013). Pemahaman guru terhadap isi pembelajaran merupakan suatu yang penting terkait dengan persiapan pembelajaran (Mizzi, 2013).

Demikian pula pada pelaksanaan asesmen autentik ataupun asesmen pada kurikulum baru. Ada berbagai hambatan yang dihadapi guru-guru pada umumnya atau guru matematika. Hambatan tersebut yakni kurangnya pemahaman guru terhadap penilaian alternatif (Eraslan, 2013), perencanaan penilaian, implementasi penilaian, penggunaan metode yang bervariasi dalam penilaian dan waktu penilaian (Lumadi, 2013), kurangnya pemahaman guru dalam melaksanakan penilaian, kurangnya sumber dalam melakanakan penilaian sumatif dan formatif (Kurebwa \& Nyaruwata, 2013), sumberdaya dan kebijakan (Kankam, Bordoh, Eshum, Bassaw, \& Korang, 2014).

Untuk mengatasi adanya hambatan-hambatan yang dialami guru dalam melaksanakan kurikulum, perlu ada tindakan khusus sehingga permasalahan dapat diselesaikan. Pakar-pakar kurikulum menyarankan adanya monitoring dan evaluasi. Pada implementasi kurikulum, guru sebaiknya dimonitor dan didukung agar fokus pada kualitas pembelajaran (Makeleni \& Sethusa, 2014). Hasil monitoring ini dapat dijadikan bahan untuk perbaikan pelaksanaan kurikulum dan juga proses pengembangan kurikulum (Hussain, Adeeb, Aslam, 2011).

Seiring realitas Kurikulum 2013 yang dilaksanakan, diperlukan suatu informasi menge- nai hambatan guru dalam melaksanakannya, khususnya untuk mata pelajaran matematika. Informasi ini dapat dimanfaatkan sebagai bahan masukan bagi pembuat kebijakan sehingga pelaksanaan kurikulum menjadi lebih baik dan lebih efisien. Terkait dengan hal ini, penelitian ini bertujuan untuk mendeskripsikan hambatan guru matematika SMP dalam mengimplementasikan Kurikulum 2013.

\section{METODE}

Penelitian ini merupakan penelitian deskriptif eksploratif, dengan mendeskripsikan dan menemukan hambatan-hambatan guru matematika SMP dalam menerapkan kurikulum baru, khususnya Kurikulum 2013. Studi ini menggunakan pendekatan kualitatif, dengan menggunakan tradisi fenomenologi. Tradisi ini digunakan untuk menggambarkan hambatan-hambatan guru dalam menerapkan kurikulum berdasarkan pengalaman guru.

Data mengenai kesulitan guru mengimplementasikan kurikulum dikumpulkan dengan teknik wawancara dan focus group discussion. Sumber data adalah 10 guru matapelajaran matematika SMP. Guru-guru matematika tersebut merupakan guru matematika dari sekolah-sekolah yang telah menerapkan Kurikulum 2013 yang berasal dari 4 kabupaten dan 1 kota di Provinsi Daerah Istimewa Yogyakart kelas VIII SMP, minimal satu semester, baik sekolah negeri maupun sekolah swasta. Masing-masing sekolah diwakili satu orang guru matematika, dan tiap kabupaten/kota diwakili oleh dua sekolah. Sekolah-sekolah tersebut yaitu: SMPN 1 Kota Yogyakarta, SMP Islam Terpadu Abu Bakar Yogyakarta, SMPN 3 Banguntapan Bantul, SMP Islam Terpadu Luqman Al-Hakim, SMPN 1 Wonosari Gunungkidul, SMPN 1 Paliyan Gunungkidul, SMPN 1 Sleman, SMPN 4 Gamping Sleman, SMPN 1 Wates Kulonprogo, dan SMPN 1 Lendah Kulonprogo.

Pengumpulan data dilakukan dengan focused group discussion (FGD) dan wawancara mendalam. Pada awalnya, dilakukan FGD terlebih dahulu untuk menjaring permasalahan umum. Selanjutnya, dilakukan wawancara individual dengan guru dengan semi terstruktur 
untuk memeroleh data yang kredibel selama dua kali, pada bulan Mei 2015 dan bulan Agustus 2015. Bahan FGD dan wawancara meliputi (1)persiapan pelaksanaan Kurikulum 2013 yang berupa pelatihan dan sosialisasi; (2) perencanaan pembelajaran; (3) pelaksanaan pembelajaran; dan (4) pelaksanaan penilaian dan pelaporan. Pada studi ini, peneliti sendiri merupakan instrumen yang utama.

Data catatan hasil FGD dan wawancara kemudian direduksi. Hasil reduksi ini kemudian disajikan dalam tabel dan dicari subtemanya dalam kelompok yang relatif kecil. Selanjutnya, antarsubtema-subtema dicari temanya. Analisis data dilakukan dengan menentukan hubungan antartema untuk memeroleh pemahaman dengan menggunakan model Bogdan \& Biklen (1982). Pada studi ini, hubungan antartema digunakan untuk memeroleh pemahaman mengenai hambatan-hambatan guru melaksanakan $\mathrm{Ku}$ rikulum 2013.

\section{HASIL DAN PEMBAHASAN Hasil}

Hasil wawancara dikelompokan sesuai dengan empat tema yang menjadi bahan wawancara untuk dikroscek, kemudian direduksi dan dicari sub-subtemanya. Setelah itu, dihubungkan antarsub-temanya untuk mendapatkan kesimpulan akhir. Pada penelitian ini, ditemukan empat tema untuk memahami hambatan guru matematika dalam melaksanakan Kurikulum 2013 yakni (1) pelatihan dan sosialisasi; (2) perencanaan pembelajaran; (3) pelaksanaan pembelajaran; dan (4) pelaksanaan penilaian dan pelaporan. Masing-masing tema yang ditemukan disajikan sebagai berikut.

\section{Pelatihan dan Sosialisasi}

Kurikulum 2013 adalah kurikulum terbaru yang beberapa waktu lalu sempat dilaksanakan secara serempak oleh seluruh sekolah. Namun beberapa waktu lalu dengan berbagai alasan keluar kebijakan kotroversi menunda pemberlakuan Kurikulum 2013. Dalih mendasar yang melatarbelakangi kebijakan tersebut adalah permasalahan kesiapan penyelenggara pendidikan. Pemerintah baru menemukan data bah- wa masih banyak sekolah yang belum siap dan terkesan dipaksakan untuk mengikuti sistem. Padahal, pemeritah terdalu telah mengupayakan berbagai macam sosialisasi dan pelatihan. Namun, ternyata masih terdapat banyak masalah yang didapatkan di lapangan. Berdasarkan hasil analisis data penelitian, ada empat sub-tema yang ditemukan untuk tema pelatihan dan sosialisasi seperti disajikan pada Tabel 1.

Kualitas proses pelatihan dan sosialisasi adalah pondasi dari keberhasilan implementasi kurikulum. Semua guru yang menjadi informan menyatakan pernah mengikuti pelatihan dan sosialisasi. Masalah yang sering mucul pada proses pelatihan dan sosialisasi adalah munculnya interpretasi yang beragam antarpemateri. Sering sekali terdapat perbedaan pendapat antarpemateri satu dengan yang lain. Kondisi tersebut mengakibatkan kebingungan pada peserta. Masalah lain pada proses pelatihan dan sosialisasi adalah waktu yang terlalu singkat. Penyelenggaraan pelatihan dan sosialisasi secara masal untuk semua guru mengharuskan adanya pembagian angkatan sehingga tiap angkatan mendapatkan waktu yang terbatas. Permasalahan bertambah rumit ketika sedikitnya waktu tidak diimbangin dengan konsep pelathan dan sosialisasi yang belum matang. Seringkali proses pelatihan dan sosialisasi tidak efektif dan efisien. Masih banyak materi yang belum disampaikan secara detail. Imbasnya adalah wawasan guru yang masih belum cukup memadai untuk bekal implementasi Kurikulum 2013.

Beberapa contoh pernyataan guru yang mendukung tema pelatihan dan sosialisasi kurikulum sebagai berikut.

"Pada pelatihan, ada pemateri yang menjelaskan seperti ini.... Pemateri lain seperti itu, jadinya kami malah bingung...." (Guru 1)

"Pelatihannya hanya sehari kok, mulai dari pembukaan, pemahaman kurikulum itu sendiri, pembelajaran, penilaian, dan pengisian rapor, jadi waktu belum cukup....ketika pelatihan, pelatihnya lebih banyak cerita macammacam yang tidak terkait kurikulum..." (Guru 2)

"Permen (peraturan menteri) berubah, mbak, yang kemarin belum jelas, yang baru belum paham..."(Guru 3) 
Tabel 1. Hasil Reduksi terkait Pelatihan dan Sosialisasi Kurikulum

\begin{tabular}{lll}
\hline No. & \multicolumn{1}{c}{ Sub-tema } & Hubungan antar sub-tema \\
\hline 1. & Sering terdapat perbedaan pendangan dan interpretasi dari pemateri/ \\
narasumber satu dengan yang lain. & $\begin{array}{l}\text { Pelatihan dan sosialisasi belum } \\
\text { dapat memberikan pehamanan }\end{array}$ \\
2. Waktu pelatihan dan sosialisasi terlalu singkat. & yang baik dan menyeluruh pada \\
3. Alokasi waktu dalam pelatihan dan sosialisasi belum efektif dan efi- & gurumengenai Kurikulum 2013. \\
& sien \\
4. Seringkali terdapat perubahan aturan ditengah jalan dan tidak di- & \\
&
\end{tabular}

Tabel 2. Hasil Reduksi Terkait Perencanaan Pembelajaran

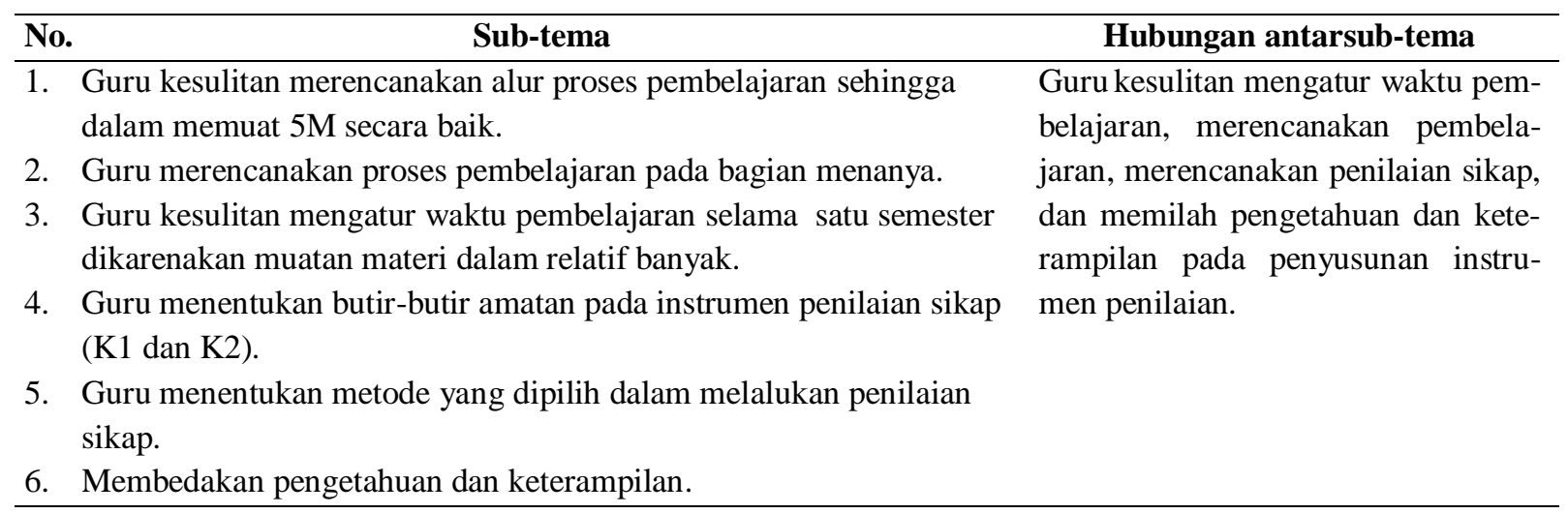

Pelatihan dilaksanakan secara berjenjang. Guru yang telah mendapatkan pelatihan diarahkan untuk membagi ilmu ke lingkup yang lebih sempit. Namun, jika ditinjau dari pemahaman guru yang belum mapan, peran guru terlatih sebagai kader masih belum efektif. Bahkan celakanya jika yang ditularkan bukan pemahaman tetapi kebingungan. Dipastikan ketika seorang narasumber belum memahami materi maka peserta akan mengalami kebingungan saat mengikuti pelatihan dan sosialisasi.

Penyelenggaraan Kurikulum 2013 seolah belum mantap dilaksanakan. Seringkali terdapat pembenahan, bahkan sempat ada perubahan yang dinyatakan melalui revisi peraturan menteri pada pertengahan implementasi. Perubahan tidak dibarengi dengan sosialisai dan pelatihan secara menyeluruh. Guru yang telah belajar melalui pelatihan dan sosialisasi atau belajar secara mandiri mengenai peraturan kurikulum 2013 sebelum proses revisi harus kembali menyelaraskan wawasannya. Proses penyelarasan secara mandiri membutuhkan waktu dan tidak menjamin guru dapat memiliki pemahaman sesuai dengan kurikulum berlaku. Seharusnya ke- tika ada revisi, pemerintah memfasilitasi proses update informasi pada setiap guru.

\section{Perencanaan Pembelajaran}

Sebelum melaksanakan proses pembelajaran, guru harus menyiapkan rencana pelaksanaan pembelajaran (RPP). Beberapa bagian yang khas menurut Kurikulum 2013 adalah rencana proses pembelajaran dan penilaian. Proses pembelajaran khas dibandingkan kurikulum sebelumnya karena menggunakan metode ilmiah (saintifik) dengan muatan 5M (mengamati, menanya, menyimpulkan, mengasosiasi, dan mengomunikasikan). Begitu pula penilaian, dibandingkan dengan Kurikulum 2013, muatan penilaian sangat khas karena memuat 4 kompetensi, yaitu kompetensi sikap spiritual (K1), kompetensi sikap sosial (K2), kompetensi pengetahuan (K3) dan kompetensi ketrampilan (K4). Kekhasan ini yang menimbulkan kesulitan guru. Kesulitan-kesulitan guru pada pelaksanaan pembelajaran direduksi, hasilnya disajikan pada Tabel 2 . 
Dalam penyusunan rencana proses pembelajaran guru relatif kesulitan dalam menyusun alur pembelajaran sehingga memuat $5 \mathrm{M}$ secara baik. Salah satu yang paling membuat guru kesulitan adalah fase "menanya". Pada dasarnya fase menanya telah dianjurkan pada implementasi kurikulum sebelumnya secara implisit dan belum tegas. Fakta lapangan pada implementasi kurikulum sebelumnya kemampuan menanya siswa masih belum berkembang. Penekanan yang tidak tegas membuat muatan tersebut dipandang tidak wajib sehingga dalam proses pembelajaran kurang diperhatikan. Siswa masih belum terbiasa untuk mengkritisi materi pembelajaran dan melayangkan pertanyaan. Guru juga belum terbiasa dalam memberikan stimulus pada siswa agar bertanya. Fakta tersebut membuahkan permasalahan pokok karena dengan tegas Kurikulum 2013 meletakan aspek menanya pada pondasi proses pembelajaran.

Mengenai ranah materi, guru dituntut harus membuat rencana proses pembelajaran yang dapat menyelesaikan seluruh materi sesuai dengan waktu yang relevan. Namun, terdapat berbagai perbedaan muatan materi yang diajarkan antara Kurikulum 2013 dan kurikulum sebelumnya. Secara umum, dalam pembelajaran matematika muatan materi meningkat. Guru merasa muatan materi tidak seimbang dengan alokasi waktu yang disediakan. Guru berpendapat bahwa jika materi disampaikan dengan proses pembelajaran konvensional kemungkinan dapat diselesaikan dengan tepat waktu. Namun ketika disampaikan dengan alur 5M, maka guru kesulitan menemukan komposisi alur yang relevan. Fase $5 \mathrm{M}$ yang menuntut siswa aktif dan guru sebagai fasilitator membuat guru harus menyediakan waktu yang lebih banyak. Hal ini menunjukkan bahwa muatan materi matematika dalam Kurikulum 2013 jika menggunakan 5M masih kurang mencukupi dibandingkan dengan alokasi waktu pembelajaran yang tersedia.

Menyoroti kesulitan guru dalam membuat rencana penilaian, Kurikulum2013 menuntut guru untuk dapat mengamati K1, K2, K3, dan K4, kemudian menyimpulkannya dalam suatu nilai. Permasalahan pada umumnya menyangkut sistem penilaian K1 dan K2. Kuriku- lum 2013 mengarahkan guru agar melakukan penilaian menggunakan teknik observasi, penilaian diri atau penilaian antarteman. Masalah pertama ada pada proses pemilihan instrumen yang tepat untuk mengukur K1 dan K2. Ketepatan pemilihan merujuk pada kefektifan, keefisienan dan objektifitas sistem penilaian. Menurut responden, banyak guru di sekolah yang masih belum memahami sistem penilaian sikap yang baik dan benar.

Masalah lain ada pada proses penyusunan instrumen penilaian. Guru masih kesulitan dalam mengembangkan instrumen penilaian sikap. Masalah pertama adalah kesulitan dalam menentukan indikator sikap yang akan dikur. Guru harus memperhatikan indikator sikap dengan materi pembelajaran dan rancangan proses pembelajaran. Jika guru tidak jeli, maka dimungkinkan indikator yang dipilih sulit untuk diukur dalam proses pembelajaran. Masalah kedua adalah penjabaran tiap indikator sehingga menjadi butir instrumen yang dapat diamati dan diukur. Proses penjabaran dimulai dengan membuat defini operasional sikap yang akan diukur dari berbagai teori. Definisi operasional kemudian dikembangkan menjadi berbagai butir muatan. Sebagian besar guru masih belum terbiasa dalam melakukan penyusunan instrumen penilaian sikap. Bahkan, beberapa informan menyatakan masih ragu dengan validitas instrumen yang digunakan dalam proses penilaian sikap.

Contoh pendapat guru yang sesuai

dengan tema kedua sebagai berikut.

“... saya sulit mengatur alur 5M, apakah boleh tidak urut ya" (Guru 3)

"...kalau bagian menanya, apa yang harus direncanakan,,," (Guru 3,4)

“... pembelajaran dengan $5 \mathrm{M}$ memerlukan waktu yang lama, saya kesulitan mengatur waktu pembelajaran karena muatan materi banyak, takut materi tidak selesai...." (Guru 5)

“... pada perencanaan penilaian sikap, belum tahu butir yang akan diamati, pakai penilaian seperti apa belum tahu." (Guru 6)

“...pada matematika...keterampilan dan pengetahuan sulit dibedakan apalagi diukur secara terpisah.... Punya keterampilan pemecahan masalah kalau sudah memiliki pengetahuan..." (Guru 7) 
Tabel 3. Hasil Reduksi Terkait Pelaksanaan Pembelajaran

\begin{tabular}{|c|c|c|}
\hline No. & Sub-Tema & Hubungan antarsub-Tema \\
\hline 1. & Alokasi waktu dan muatan materi tidak seimbang. & Guru memerlukan waktu \\
\hline & $\begin{array}{l}\text { Guru kehabisan waktu ketika menyampaikan materi sesuai dengan ran- } \\
\text { cangan pembelajaran khususnya di kelas yang siswa-siswanya kemam- } \\
\text { puannya kurang. }\end{array}$ & lama untuk pembelajaran \\
\hline & $\begin{array}{l}\text { Guru harus memberikan tugas yang relatif berat dan banyak untuk menutupi } \\
\text { kekurangan waktu guru dalam menyampaikan materi. }\end{array}$ & \\
\hline & $\begin{array}{l}\text { Kepercayaan diri siswa untuk berpendapat dan menyampaikan pertanyaan } \\
\text { masih kurang. }\end{array}$ & $\begin{array}{l}\text { Kepercayaan diri siswa ma- } \\
\text { sih kurang }\end{array}$ \\
\hline & $\begin{array}{l}\text { Sering ditemukan ketidakselarasan antara silabus dengan materi yang } \\
\text { terangkup dalam sumber belajar. } \\
\text { Susunan materi dalam buku tidak sistematis sehingga pada proses pem- } \\
\text { belajaran sering kali terkendala karena siswa belum menguasai materi } \\
\text { prasyarat. }\end{array}$ & $\begin{array}{l}\text { Silabus, susunan materi, bu- } \\
\text { ku, yang belum sesuai, sara- } \\
\text { na dan prasarana di sekolah } \\
\text { belum mendukung pelaksa- } \\
\text { naan pembelajaran. }\end{array}$ \\
\hline & $\begin{array}{l}\text { Sering ditemukan kesalahan materi pada sumber belajar yang dikeluarkan } \\
\text { oleh kementerian. }\end{array}$ & \\
\hline & $\begin{array}{l}\text { Sarana dan prasarana di sekolah masih belum mendukung untuk pelak- } \\
\text { sanaan pembelajaran saintifik. }\end{array}$ & \\
\hline & Guru kesulitan dalam mengaktifkan kelas. & Guru kesulitan dalam pelak- \\
\hline & $\begin{array}{l}\text { Guru seringkali tidak sabar dalam menyampaikan materi sesuai dengan } \\
\text { rancangan pembelajaran karena pembelajaran saintifik memerlukan waktu } \\
\text { yang sangat lama. } \\
\text { Keterlaksanaan rancangan pembelajaran masih kurang baik. }\end{array}$ & $\begin{array}{l}\text { sanaan pembelajaran ketika } \\
\text { mengaktifkan kelas dan me- } \\
\text { nyesuaikan rancangan pem- } \\
\text { belajaran. }\end{array}$ \\
\hline
\end{tabular}

\section{Pelaksanaan Pembelajaran}

Pembelajaran merupakan salahsatu esensi dalam pelaksanaan kurikulum. Pada pembelajaran matematika, ada berbagai kesulitan yang dihadapi guru. Kesulitan tersebut disajikan pada hasil reduksi pada Tabel 3.

Pelaksanaan pembelajaran adalah realisasi dari rancangan pembelajaran yang telah dibuat oleh guru. Beberapa permasalahan yang ditemukan dalam proses pembelajaran memiliki keterkaitan dengan pelaksanaan pembelajaran. Masalah menanya yang dipermasalahkan dalam proses perencanaan muncul kembali pada proses pelaksanaan pembelajaran. Guru kesulitan untuk mengondisikan siswa aktif bertanya. Melalui penelusuran yang lebih detail di lapangan ditemukan data bahwa kepercayaan diri siswa dalamberpendapat masih kurang. Berbagai upaya telah dilakukan oleh guru, namun sepuluh guru yang menjadi informan sepakat bahwa siswa masih sulit untuk dikondisikan menanya dalam pembelajaran matematika. Saat masuk dalam fase menanya, siswa cenderung diam.
Bahkan, ketika "guru memaksa siswa" untuk bertanya, siswa seringkali tetap diam. Jika diberikan stimulus secara telaten mungkin fase ini dapat berjalan dengan baik, namun membutuhkan waktu yang relatif lama. Jika melihat kembali alokasi waktu yang dijadwalkan maka guru terpaksa harus mengesampingkan aspek menanya. Pada umumnya, guru hanya sekedar memberikan waktu menanya dan apabila tidak ada respon maka masuk ke fase berikutnya.

"Menyelesaikan materi" adalah hal yang sering menjadi dalih guru untuk tidak melaksanakan proses pembelajaran sesuai dengan rancangan pembelajaran. Idealnya, proses pembelajaran yang menggunakan alur 5M dihiasi dengan keaktifan siswa dan kebermaknaan materi. Namun, beberapa strategi pembelajaran berbasis saintifik dipandang membutuhkan waktu yang relatif lama. Jika merujuk pada muatan materi dan alokasi waktu yang dipandang tidak seimbang, kebanyakan guru mengungkapkan rasa pesimis sehingga seringkali keterlaksanaan rancangan pembelajaran pun masih sangat ku- 
rang. Strategi guru untuk dapat menyampaikan materi di tengah terbatasnya waktu adalah dengan memberikan tugas pada siswa. Hampir semua guru mapel memiliki strategi demikian sehingga volume tugas siswa sangat banyak. Hal tersebut sering menimbulkan keluhan dari orang tua siswa.

Mengenai sarana dan prasarana yang dibutuhkan untuk mendukung kelancaran proses belajar belum bisa dikatakan ideal. Masih banyak bagian yang harus disempurnakan. Buku ajar adalah salah satu fasilitas yang disediakan oleh pemerintah guna menunjang dan memudahkan proses pembelajaran. Namun, masih ditemukan buku dengan konten yang salah secara konsep maupun penulisan. Kondisi tersebut dapat memberikan pengaruh pada proses belajar. Kemungkinan pertama adalah siswa kebingungan dan kemungkinan kedua adalah siswa mengalami miskonsepsi. Hal tersebut menuntut kejelian dan ketelatenan guru dalam merevisi dan melakukan klarifikasi pada siswa. Masalah lain mengenai materi adalah runtutannya. Beberapa guru menyatakan bahwa beberapa materi belum runtut sehingga siswa kebingungan karena belum menguasai materi prasyarat. Kondisi demikian membuat efisiensi waktu terganggu karena guru harus meluangkan waktu untuk membekali siswa dengan materi prasyarat.

Contoh pendapat guru yang sesuai dengan tema pelaksanaan pembelajaran sebagai berikut.

“ Untuk kelas yang siswanya banyak yang kemampuannya kurang, saya kehabisan waktu ketika melaksanakan pembelajaran dengan rancangan pembelajaran ......" (Guru 2)

"Untuk mengejar materi agar selesai, saya harus memberikan tugas atau pekerjaan rumah yang cukup banyak...mungkin memberatkan siswa..." (Guru 3)

"Untuk menyapaikan ide atau pertanyaan atau mempresentasikan sesuatu, siswa masih kurang percaya diri..." (Guru 4)

"Silabus dan materi kok tidak sesuai ya... silabus soalnya dibuatkan.... juga susunan materi kok tidak urut...jadi sulit mengampunya...." (Guru 7)
"Pada buku resmi dari pemerintah, sering ditemukan kesalahan materi ....” (Guru 8)

"Untuk pembelajaran saintifik, perlu alat macam-macam, guru harus mencari sendiri...." (Guru 9)

"Membuat siswa bertanya, menjawab, ikut presentasi sulit sekali.... “(Guru 5)

"Pembelajaran saintifik memerlukan waktu yang sangat lama, saya seringkali tidak sabar mengampu sesuai rancangan pembelajaran ..... ujungnya, keterlaksanaan rancangan pembelajaran masih kurang baik." (Guru 10)

\section{Penilaian dan Pelaporan Hasil Belajar}

Pelaksanaan penilaian dan pelaporan hasil belajar menggunakan kurikulum baru merupakan salah satu masalah yang banyak dihadapi dan dikeluhkan oleh guru-guru matematika dalam proses implementasi Kurikulum 2013. Untuk Hasil reduksi data disajikan pada Tabel 4.

Semua guru yang menjadi responden mengeluhkan bahwa sistem penilaian yang berlaku terlalu rumit. Aspek yang dinilai dalam proses pembelajaran terlalu banyak. Guru mengalami kesulitan saat penilaian, terutama untuk penilaian sikap. Sebagian besar guru memilih teknik observasi yang memungkinkan guru lebih leluasa secara waktu mengambil data. Namun, proses penilaian seringkali mengganggu fokus guru dalam mengajar. Jika penilaian dilakukan dengan penilaian diri atau penilaian antarteman, guru mengeluhkan waktu pengambilan nilai dan borosnya lembar penilain yang harus dipersiapkan.

Saat ini, wawasan guru mengenai teori penilaian sikap masih dianggap kurang. Hal tersebut nampak dari masalah pemilihan teknik dan penjabaran indikator yang masih menjadi kendala dalam penyusunan rencana penilaian. Beberapa guru mengemukakan masih ragu mengenai kesahihan proses penilaian yang dilakukan. Saat ditanya mengenai objektifitas nilai, guru masi ragu dalam menjawabnya. Guru mengakui bahwa proses penilaian sikap yang dilakukan masih dipengaruhi oleh unsur subjektivitas. 
Tabel 4. Hasil Reduksi Terkait Penilaian dan Pelaporan Hasil Belajar

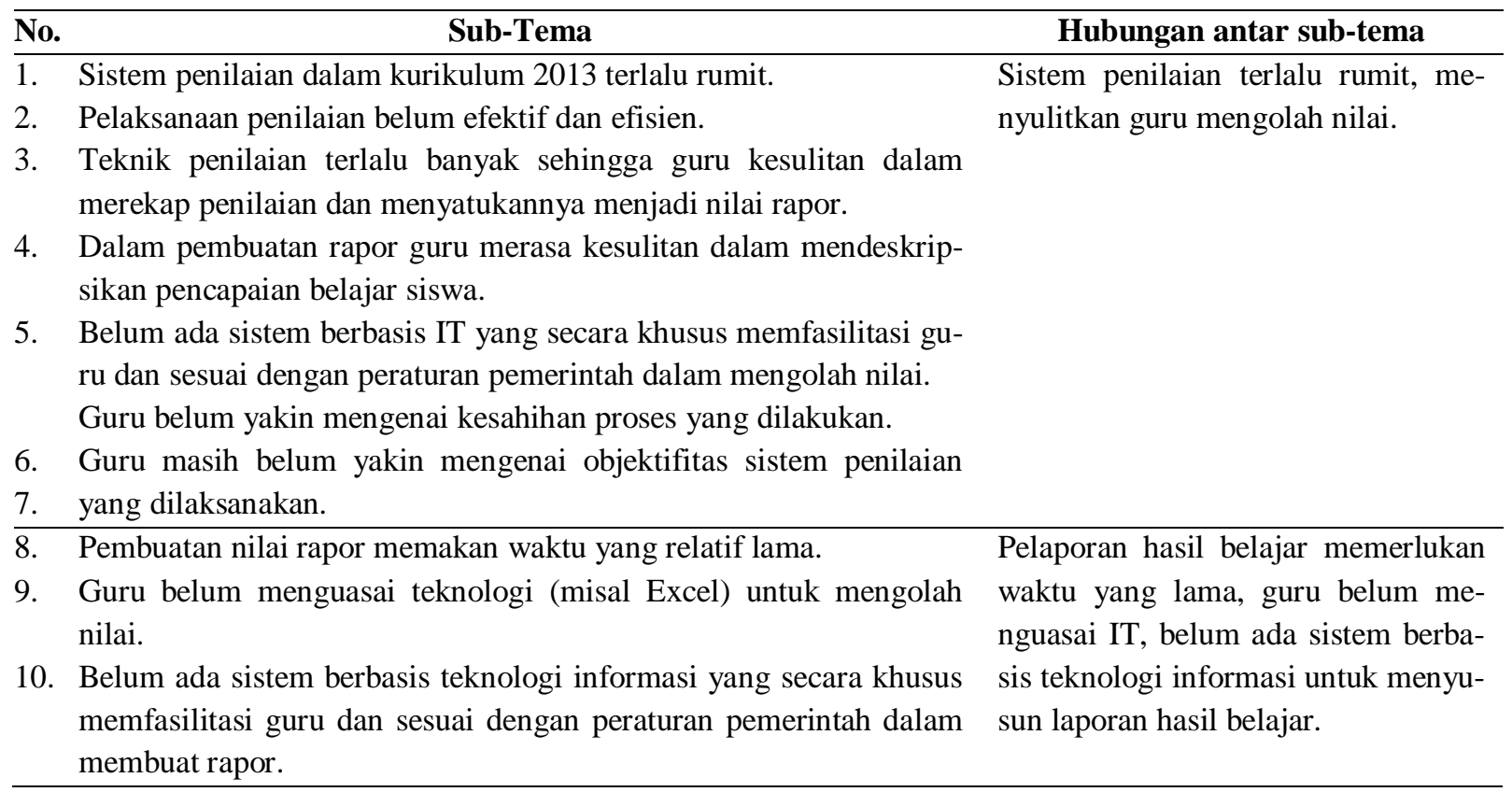

Rekap data penilaian adalah masalah lanjutan yang menjadi konsekuensi nyata. Guru mengalami kesuitan dalam rekap data yang begitu banyak. Guru memiliki himpunan data nilai sikap, pengetahuan, dan ketrampilan yang harus direkap lalu diolah dalam sebelum penulisan rapor. Proses rekap dan olah data tersebut dianggap menyulitkan guru karena membutuhkan waktu yang relatif lama. Masalah bertambah ketika seorang guru tidak familiar dengan teknologi informasi sehingga tidak dapat dimanfaatkan sebagai sarana mempermudah penilaian. Beberapa sekolah telah berinisiatif untuk membuat suatu form Excel yang dapat membantu guru dalam merekap dan mengolah nilai. Namun, ternyata masih banyak pula guru yang belum mampu memanfaatkan excel dengan baik karena wawasan teknologi informasi yang kurang.

Rapor adalah kemasan akhir dari suatu penilaian. Rapor memuat kompilasi kemampuan seorang siswa. Format rapor Kurikulum 2013 pun memiliki perbedaan dengan kurikulum sebelumnya. Sepuluh informan sepakat bahwa rapor Kurikulum 2013 rumit. Rapor dipenuhi dengan deskripsi hasil belajar siswa. Pembuatan deskripsi tersebutlah yang menjadi masalah. Masih banyak guru yang belum terbiasa menulis sehingga proses penulisan deskripsi serasa rumit dan memerlukan waktu yang relatif lama.

Penulisan rapor sendiri melibatkan guru mapel dan wali kelas. Kolaborasi tersebut sering terkendala karena saling tunggu. Selain itu, petugas yang menulis rapor harus menunggu guru mapel menyetorkan nilai. Di lapangan sistem tersebut sering menemukan masalah. Efisiensi waktu sering tidak terjangkau karena beberapa guru mapel belum siap dengan nilai-nilainya. Dibutuhkan suatu sistem yang dapat memfasilitasi guru dalam menulis rapor. Efisiensi waktu dan energi adalah fokus kebutuhan. Guru membutuhkan suatu sistem yang dapat menghubungkan antarpenilai dan merangkumnya dalam satu bendel rapor dengan mudah.

Contoh pernyataan guru yag mendukung tema pelaksanaan penilaian dan pelaporan hasil belajar sebagai berikut.

“... penilaian dalam Kurikulum 2013 rumit sekali...” (Guru 1)

“...saya belum percaya diri, saya merasa penilaian belum efektif dan efisien...." (Guru 2)

"teknik penilaian sikap ada empat, pengetahuan ada tiga, keterampilan ada tiga, terlalu banyak, melaksanakannya sulit, merekapnya repot, terus menyatukan hasilnya bagaimana..." (Guru 3) 
“apalagi rapornya, kami merasa kesulitan menyusunnya... mendeskripsikan banyak.... padahal siswanya juga banyak...." (Guru 4)

" kami perlu IT, apa software begitu, bisa tidak ya...kalau termasuk mengolah nilai dan mendeskripsikannya?" (Guru 5)

"kalau banyak begini yang dinilai, kok tidak yakin mengenai hasilnya...sahih atau tidak." (Guru 6)

“apa objektif juga hasilnya?” (Guru 7)

“...bikin nilai rapornya lama.” (Guru 8)

"tidak semua dari kami menguasai teknologi (misal Excel) untuk mengolah nilai....jadi ada tim yang mengolah nilai” (Guru 9)

“....belum ada sistem berbasis teknologi informasi yang secara khusus memfasilitasi guru dan sesuai dengan peraturan pemerintah dalam membuat rapor....sehingga kami lebih mudah melaporkan.” (Guru 10)

\section{Pembahasan}

Dalam suatu pelaksanaan kurikulum, pelatihan dan sosialisasi kurikulum merupakan hal yang sangat menentukan. Pelaksanaan pelatihan dan sosialisasi yang efektif dan efiien kepada guru akan memberikan jaminan bahwa guru yang mengikuti pelatihan tersebut dapat memeroleh pemahaman yang baik tentang kurikulum. Pemahaman ini tentunya menjadi salah satu faktor penentu keberhasilan implementasi kurikulum. Pada penelitian ini, pelatihan dan sosialisasi Kurikulum 2013 yang dilaksanakan belum efektif dan efisien dengan indikator adanya interpretasi beragam dari pemateri, waktu pelatihan dan sosialisasi yang terbatas, kuantitas dan kualitas materi pelatihan belum memadai, yang menyebabkan kekurangpahaman guru mengenai kurikulum. Hasil penelitian ini sesuai dengan hasil penelitian yang telah dilakukan peneliti sebelumnya, yakni Park (2008) dan Cheung dan Wong (2012).

Kesulitan guru dalam merencanakan pembelajaran merupakan bagian dari dampak kekurangpahaman guru terhadap kurikulum. Kekurangpahaman ini menyebabkan guru kesulitan mendesain pembelajaran saintifik ataupun pendekatan lain yang direkomendasikan kurikulum, kesulitan merencanakan penilaian, dan kesulitan menyusun instrumen penilaian sikap. Kesulitan-kesulitan guru tersebut senada dengan hasil penelitian Lumadi (2013).

Melaksanakan pembelajaran saintifik dengan mengaktifkan siswa juga merupakan kesulitan guru. Kesulitan ini diakibatkan kemampuan siswa yang beragam, siswa belum terbiasa dengan pembelajaran pendekatan konstruktivisme, kurang cukupnya waktu pembelajaran, dan kurangnya sarana belajar berupa buku yang sesuai dengan Kurikulum 2013. Hal ini akan menjadi lebih rumit jika guru belum memahami sepenuhnya Kurikulum 2013, termasuk proses pembelajaran sekaligus muatan isinya sebagai bahan yang dibahas dalam pembelajaran. Hasil penelitian ini sejalan dengan penelitian Eraslan (2013) dan Syomwene (2013), dan Mizzi (2013).

Pelaksanaan penilaian, baik proses dan hasil belajar serta menyusun laporan hasil belajar menggunakan Kurikulum 2013 merupakan kendala yang paling besar. Kendala ini disebabkan adanya empat kompetensi yang dinilai, yaitu kompetensi sikap spiritual (KI1), kompetensi sikap sosial (KI2), kompetensi pengetahuan (KI3) dan kompetensi keterampilan (KI4). Teknik penilaian yang digunakan juga sangat banyak. Pelaporan menggunakan sistem deskripsi tiap siswa tiap matapelajaran pada keseluhuhan kompetensi. Permasalahan menjadi lebih rumit karena tiap kelas/rombongan belajar kurang lebih 30 siswa. Kekurangpahaman guru mengenai penilaian menyebakan permasalahan penilaian dan pelaporan menjadi sangat kompleks. Hasil ini sejalan dengan penelitian Lumadi (2013) dan Kurebwa \& Nyaruwata (2013).

Kesulitan-kesulitan guru dalam mengimplementasikan kurikulum sebenarnya dapat diatasi. Untuk mengatasi kesulitan-kesulitan tersebut, Mayer dan Fortner (1987) menyarankan desiminasi kurikulum melalui workshop yang intensif. Dengan workshop yang intensif, pemahaman guru terhadap kurikulum yang baru diterapkan menjadi lebih baik sehingga dapat mendesain pembelajaran, melaksanakan pembelajaran, dan melakukan penilaian dengan baik sesuai kurikulum yang diberlakukan. Cara lain mengatasi kesulitan-kesulitan guru untuk meng- 
implementasikan kurikulum perlu dikaitkan dengan pengembangan keprofesionalan guru (Ryder, Banner, \& Homer, 2014). Selain itu, diperlukan juga manajemen pelatihan dan sosialisasi kurikulum yang baru (Katuuk, 2014). Hal ini dapat dilakukan secara real dengan melalui pertemuan intensif pada organisasi profesi guru, forum guru seperti musyawarah guru mata pelajaran (MGMP), penulisan karya ilmiah, maupun program pendampingan guru senior ke guru yunior. Upaya ini menjamin pelaksanaan $\mathrm{ku}-$ rikulum akan menjadi lebih baik.

\section{PENUTUP}

\section{Simpulan}

Berdasarkan hasil analisis, diperoleh bahwa hambatan guru matematika SMP pada implementasi Kurikulum 2013 meliputi hal-hal sebagai berikut. Pertama, pelatihan dan sosialisasi belum dapat memberikan pehamanan yang baik dan menyeluruh pada guru mengenai kurikulum 2013. Kedua, guru kesulitan mengatur waktu pada perencanaan pembelajaran, merencanakan pembelajaran, merencanakan penilaian sikap, dan memilah pengetahuan dan keterampilan pada penyusunan instrumen penilaian. Ketiga, pada pelaksanaan pembelajaran waktunya terbatas, kesulitan terkait dengan perangkat pembelajaran, dan kesulitan mengaktifkan siswa. Keempat, sistem penilaian yang rumit dan perlu waktu yang lama untuk menyusun laporanya.

\section{Saran}

Untuk mengatasi hambatan ini, pelatihan yang efektif perlu dilakukan yang meliputi isi Kurikulum 2013, pembelajaran, dan asesmen, termasuk pelaporan hasil belajar khususnya untuk guru matematika. Pelatihan seperti ini perlu melibatkan semua guru matematika. Jika diperlukan, pelatihan dapat diformat dalam pengembangan profesi guru matematika. Selama pelaksanaan kurikulum, program monitorning dan pendampingan juga diperlukan sehingga jika guru mengalami hambatan-hambatan, maka guru dapat memeroleh solusi dengan cepat. Dukungan baik berupa kebijakan maupun sarana atau fasilitas pembelajaran juga akan mempermudah guru melaksanakan kurikulum.

\section{UCAPAN TERIMA KASIH}

Terima kasih diucapkan Dr. Hartono selaku Dekan FMIPA dan Dr. Sugiman selaku Ketua Jurusan Matematika Universitas Negeri Yogyakarta yang telah memberikan kemudahan fasilitas selama melakukan penelitian mandiri, Bapak/Ibu Guru SMP di Provinsi Daerah Istimewa Yogyakarta yang telah berkenan menjadi partisipan penelitian ini, dan Janu Arlin Wibowo, M.Pd. yang telah bersedia berkolaborasi dalam penelitian ini.

\section{DAFTAR PUSTAKA}

Arends, R. I. 2012. Learning to teach ( $9^{\text {th }}$ ed.). New York, NY: McGraw-Hill.

Arends, R. I., \& Kilcher, A. 2010. Teaching for Student Learning: Becoming an Accomplished Teacher. New York, NY: Taylor $\&$ Francis.

Ariev, P.R. 2005. A Theoretical Model for the Authentic Assessment of Teaching. Practical Assessment, Research \& Evaluation. 10 (2). 1-11.

Bogdan, R. C., \& Biklen, S. K. 1982. Qualitative Research for Education: An Introduction to Theory and Methods. Boston, MA: Allyn and Bacon, Inc.

Cheung, A.C.K \& Wong, P.M. 2012. "Factors Affecting the Implementation of Curriculum Reform in Hong Kong: Key Findings from a Large-Scale Survey Study". International Journal of Educational Management, Vol. 26 Iss: 1, pp.39 - 54. Doi: http://dx.doi.org/10.1108/09513541211194374.

De Vito, A. 1989. Creative Wellsprings for Science Teaching. West Lafayette, IN: Creative Ventures.

DiMartino, J, Castameda, A. \& Miles, S. 2007. "Authentic Assessment". Principal's Research Review. 2 (4). 1-8. 
Edelson, D.C., Gordin, D.N, \& Pea, R.D. 1999. "Addressing the Challenges of InquiryBased Learning through Technology and Curriculum Design". The Journal of the Learning Sciences, 1999, 8 (3-4), pp.391450.

Eraslan, A. 2013. "Teachers' Reflections on the Implementation of the New Elementary School Mathematics Curriculum in Turkey". HU Journal of of Education. 28 (2), 152-165.

European Centre for the Development of Vocational Training. 2012. Curriculum Reform in Europe: the Impact of Learning Outcomes. Luxembourg: Publications Office of the European Union.

Gulikers, J.T.M., Bastiaens, T.J., \& Kirschner, P.A. 2004. "A Five-Dimensional Framework for Authentic Assessment". Educational Technology Research and Development, Vol. 52, No. 3 (2004), pp. 6786.

Hussain, Z., Adeeb, A., \& Aslam, H.D. 2011. "Curriculum Implementation and Feedback Mechanism at Secondary School Level in Punjab Pakistan". International Journal of Learning \& Development. 1 (2) 92-98. Doi:10.5296/ijld.v1i2.6645

Kankam, B., Bordoh, A., Eshum, I., Bassaw, T.K, \& Korang, F.Y. 2014. 'Teachers' Perception of Authentic Assessment Techniques Practice in Social Studies Lessons in Senior High Schools in Ghana”. International Journal of Educational Research and Information Science. 1 (4): $62-68$

Katuuk, D.A. 2014. Manajemen Implementasi Kurikulum: Strategi Penguatan Implementasi Kurikulum 2013. Cakrawala Pendidikan, 13 (1): 13-26.
Kurebwa, M. \& Nyaruwata, L.T. 2013. "Assessment Challenges in the Primary Schools: A Case of Gweru Urban Schools". Greener Journal of Educational Research 3 (7), pp. 336-344.

Lombardi, M.M. 2008. Making the Grade: The Role of Assessment in Authentic Learning. Eduhouse Learning Initiative, dari http://www.net.eduhouse.org Tanggal 18 Juli 2015.

Lumadi, M.W. 2013. "Challenges Besetting Teachers in Classroom Assessment: An Exploratory Perspective". Journal of Social Science. 34 (3): 211-221.

Makeleni, N.T. \& Sethusa, M.J. 2014. "The Experiences of Foundation Phase Teachers in Implementing the Curriculum". Mediterranean Journal of Social Sciences. 5 (2) 1003-109. Doi:10.5901/mjss.2014.v5n2p103.

Mergendoller, J.R., Maxwell, N.L. \& Bellisimo, Y. 2006. "The Effectiveness of ProblemBased Instruction: A Comparative Study of Instructional Methods and Student Characteristics". The Interdisciplinary Journal of Problem-Based Learning, 1, 49-69.

Massa, N.M. 2008. "Problem-Based Learning: A Real-World Antidote to the Standards and Testing Regime". The New England Journal of Higher Education, 22, 19-20.

Mayer, V.J. \& Fortner' R.W. 1987. "Relative Effectiveness of Four Modes of Dissemination of Curriculum Materials", The Journal of Environmental Education, 19 (1) 25-30. Doi:10.1080/00958964.1987.10801957.

Menteri Pendidikan dan Kebudayaan Republik Indonesia. 2013. Peraturan Menteri Pendidikan dan Kebudayaan Nomor 81 Tahun 2013 tentang Pelaksanaan Penilaian. 
Menteri Pendidikan dan Kebudayaan Republik Indonesia. 2014. Peraturan Menteri Pendidikan dan Kebudayaan Nomor 104 Tahun 2014 tentang Pelaksanaan Penilaian.

Mizzi, D. 2013. "The Challenges Faced by Science Teachers when Teaching Outside Their Specific Science Specialism". Acta Didactica Napocensia. 6 (4) 1-6.

National Council of Teacher of Mathematics (NTCM). 2000. Principles and Standards for School Mathematics. Reston, VA: NCTM.

Öztürk, I.H.. 2011. "Curriculum Reform and Teacher Autonomy in Turkey: the Case of the History Teaching". International Journal of Instruction.4(2) 113-127.

Puskurbuk. 2012. Pergeseran Paradigma Belajar Abad 21. Tersedia di http://www.puskurbuk.org pada Tanggal 1 Agustus 2015.

Ryder, J., Banner, I., \& Homer, M. 2014. "Teachers' Experiences of Science Curriculum Reform". School Science Review. 95 (352) 126-130.

So, K. \& Kang, J. 2014. “Curriculum Reform in Korea: Issues and Challenges for Twenty-First Century Learning". The AsiaPacific Education Researcher. 23 (4) 795-803.
Syomwene, A. 2013. "Factors Affecting Teachers' Implementation of Curriculum Reforms and Educational Policies in Schools: The Kenyan Experience". Journal of Education and Practice. 4 (22) 8086.

Tanja, S. 2011. "New Curriculum Reform Implementation and the Transformation of Educational Beliefs, Practices, and Structures: A Case Study of Gansu Province". Chinese Education and Society, 44 (6), 49-74. doi: 10.2753/CED1061-1932440604.

Udi, E.A \& Cheng, D. 2015. "Developing Critical Thinking Skills from Dispositions to Abilities: Mathematics Education from Early Childhood to High School". Creative Education. 2015, 6, 455-462. Doi: 10.4236/ce.2015.64045.

UNESCO. 2014. Education Systems In ASEAN +6 Countries: A Comparative Analysis of Selected Educational Issues. Paris: the United Nations Educational, Scientificand Cultural Organization.

Weissinger, P.A. 2004. Critical Thinking, Metacognition, and Problem-Based Learning. Dalam Tan, O.S. (Eds.), Enhancing Thinking through Problem- Based Learning Approaches: International Perspectives. Singapore: Cengage. 